\title{
The Influence of Progressive Mobilization on Pneumonia and Decubitus Occurrences in Critical Patients Using Mechanical Ventilator A Literature Review
}

\author{
Hanny R. Mokorimban ${ }^{1, *}$ Nur Chayati ${ }^{2}$
}

\begin{abstract}
${ }^{1}$ Master of Nursing, Post Graduate Program, Universitas Muhammadiyah Yogyakarta, Yogyakarta, Indonesia ${ }^{2}$ Master of Nursing, Post Graduate Program, Universitas Muhammadiyah Yogyakarta, Yogyakarta, Indonesia *Corresponding author. Email: hannimokorimban@gmail.com
\end{abstract}

\begin{abstract}
Background: The short-term impact felt by critically ill patients and ventilators are Ventilator-Associated Pneumonia (VAP), which is added to the health mechanism due to muscle weakness and the occurrence of pressure sores or decubitus. Prevention of pneumonia in intubation patients is crucial because it can prevent hospital-acquired or nosocomial infections, which is a severe complication. Extensive skin destruction or pressure can cause depression in the blood supply and tissue damage. Decubitus will disturb the blood that enters the depressed (stressed) area and results in tissue death. Physical activity in ICU for critical patients is needed. Progressive mobilization of patients is one of the nurse interventions for patients. Objective: This research aims to identify the effect of progressive mobilization on the formation of pneumonia and (decubitus) in critically ill patients. Method: This research is a literature review accessed from internet database searches named PubMed, Pro-Quest, and Science direct with the keywords mobilization progressive, pneumonia, pressure sores. From the PubMed database, 12473 articles were found, 28986 articles from Pro Quest and Sciencedirect resulted in 51077 articles. After going through the screening process and eligibility, 7 articles fit the inclusion criteria. Results: The stages of progressive mobilization in preventing the risk of pressure sores were developed according to the level of mobility in the Early Mobilization Protocol. Based on the results of a review of 7 articles, mobilization exercises were carried out progressively from Level 1 - Level VI with Head of Bed (HOB) activity 30 ${ }^{\circ}$ $45^{\circ}$ until the patient can walk for 2 hours, starting in the first 48 hours after entering critical care and performed every day until 7 to 13-day treatment. Conclusion: This literature review shows that progressive mobilization reduces the incidence of pneumonia in ICU care and the risk of pressure sores. Training for nurses working in critical services is needed to increase knowledge and civilize clinical practices related to progressive mobilization I.
\end{abstract}

Keywords: progressive mobilization, pneumonia, pressure sores

\section{INTRODUCTION}

Critical patients are patients who have impaired body system function or failure in one, two or more body systems that can lead to life-threatening, accompanied by the help of medical devices and providing therapy for intensive care patients as well as care in the Intensive Care Unit (ICU), [1]. The short-term impacts that can be felt by the critical patient might be Ventilator-Associated Pneumonia (VAP), ventilation mechanism delay due to muscle weakness, and pressure sores or decubitus [1].

Pneumonia prevention on intubation patients is essential because pneumonia is a negative effect of ventilation mechanism usage [2]. Pneumonia related to ventilators is well-known as infection exposed in a hospital or nosocomial, and this has been a severe complication and even fatal in patients taking general anesthesia or suffering from acute breath failure [2]. In critical patients, it is usual to use a mechanical ventilator and use sedation. The prolonged use of sedation makes the patient's body strength when moving and changes body position to experience pressure [1]. The long-pressed skin on a patient who sleeps alone will inhibit blood flow, and over time it will destroy the skin until the skin tissue dies [1]. Immobilization has been one of the most significant factors in decubitus occurrences [1].

Physical activity is needed in the initial care of critical patients in the ICU to improve hemodynamic care [1]. Progressive mobilization interventions carried out by nurses in critical patients continue to develop in 2010 in the United States with the American Association of Critical-Care Nurses (AACN), [1]. The Medical Center Hospital (MCH) explains that critical patients who use ventilation devices work together to see their mental development and body function [3]. The Institute for the Improvement of Healthcare (IHI) reports that most early patient activity (EPM) shortens the length of stay in hospital (LOS) by 4.5 days and 1.3 days and reduces the risk of complications such as ventilators and thromboembolic pneumonia associated with pressure ulcers [3].

This concept has changed patients' traditional treatment 
standard who suffers critically and treated with ventilation mechanisms, making them lie down for days or weeks [4]. This condition shows the need for cultural change in ICU treatment to insert the strategy to mobilize patients in the ICU. In the implementation, many ICUs have not changed the practice of inserting patients' mobility due to some obstacles [5]. Based on the facts, a literature review was done to see the influence of progressive mobilization on pneumonia and decubitus on critical patients.

\section{AIM}

This literature review aims to determine the impact of progressive mobilization on pneumonia and decubitus sores in critically ill patients.

\section{METHOD}

This study is a literature review to determine the impact of progressive mobilization on pneumonia and decubitus in critically ill patients. The search is limited to English articles accessed on the Internet with the database of PubMed, Pro-Quest, and Sciencedirect with the keyword mobilization progressive, pneumonia, and pressure sores. The literature search focuses on the articles published in 2010 up to 2020 . The inclusive article criteria used are the full-text article, which can be accessed without payment, quantitative study, and studies of patients without the ventilator, while the exclusive criteria were patients who had taken surgery and patients with mental problems. Articles complying with the inclusive criteria were examined and collected systematically. The search process resulted in 7 articles that satisfy the inclusive and exclusive criteria required.

\section{RESULT}

Based on the search result of 3 search engines, i.e., PubMed, Proquest, dan Sciencedirect, 92518 articles using the keywords were found. The literature was then screened according to the title. Article titles that did not correspond with the aim could not be accessed freely, and not the full text was excluded as many as 92494. Therefore, 24 articles left would take the fit and proper test. From the 24 articles after being studied, 17 articles were only in theoretical reviews, opinions, and issues from the authors and formed as systematic review and qualitative study; hence they did not meet the inclusion criteria. The last 7 articles that complied with the inclusive criteria were then researched to get the result according to the aim. 


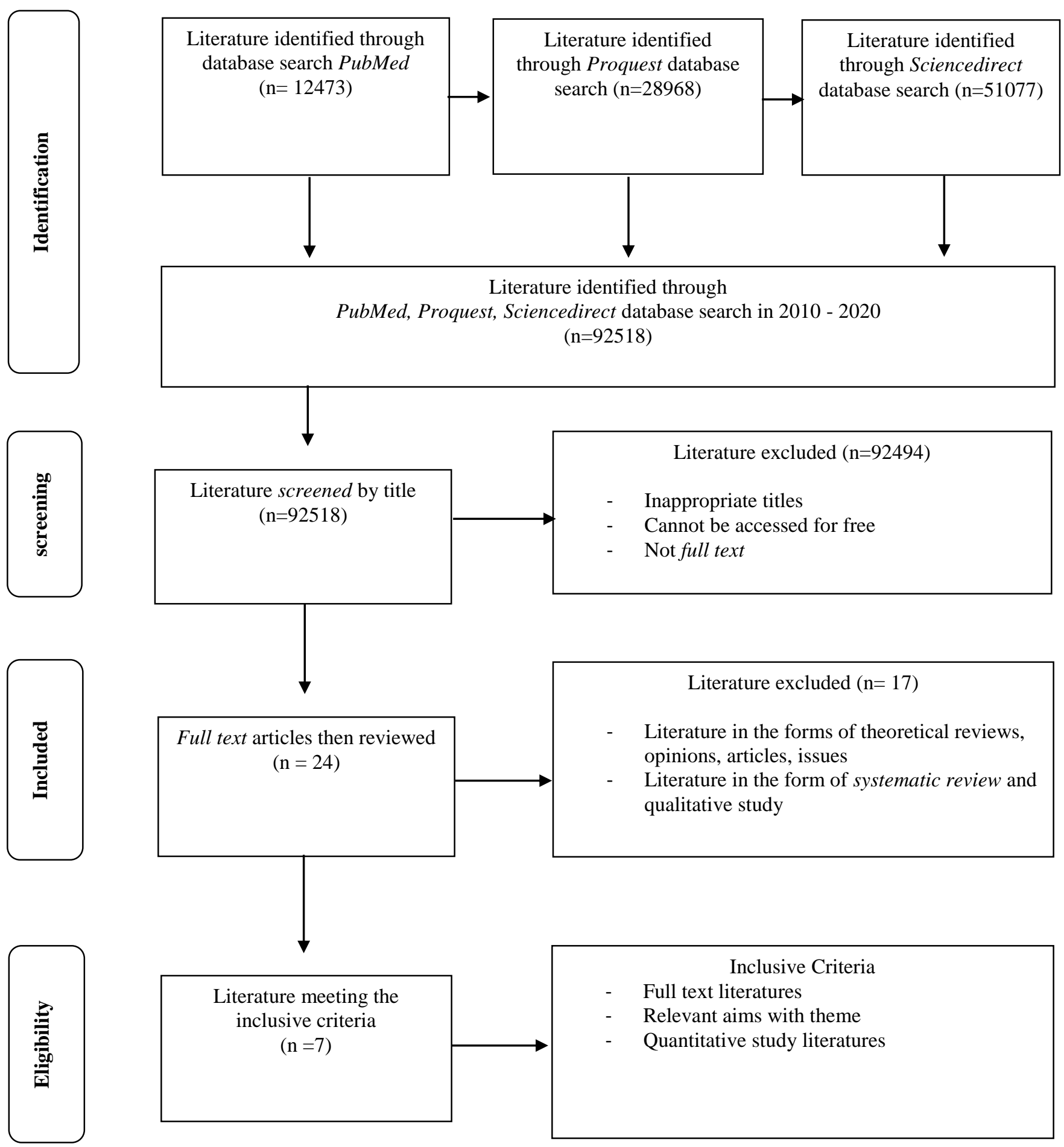

Picture 1. Literature Selection Process Diagram 
Table 1. Data Extraction Result

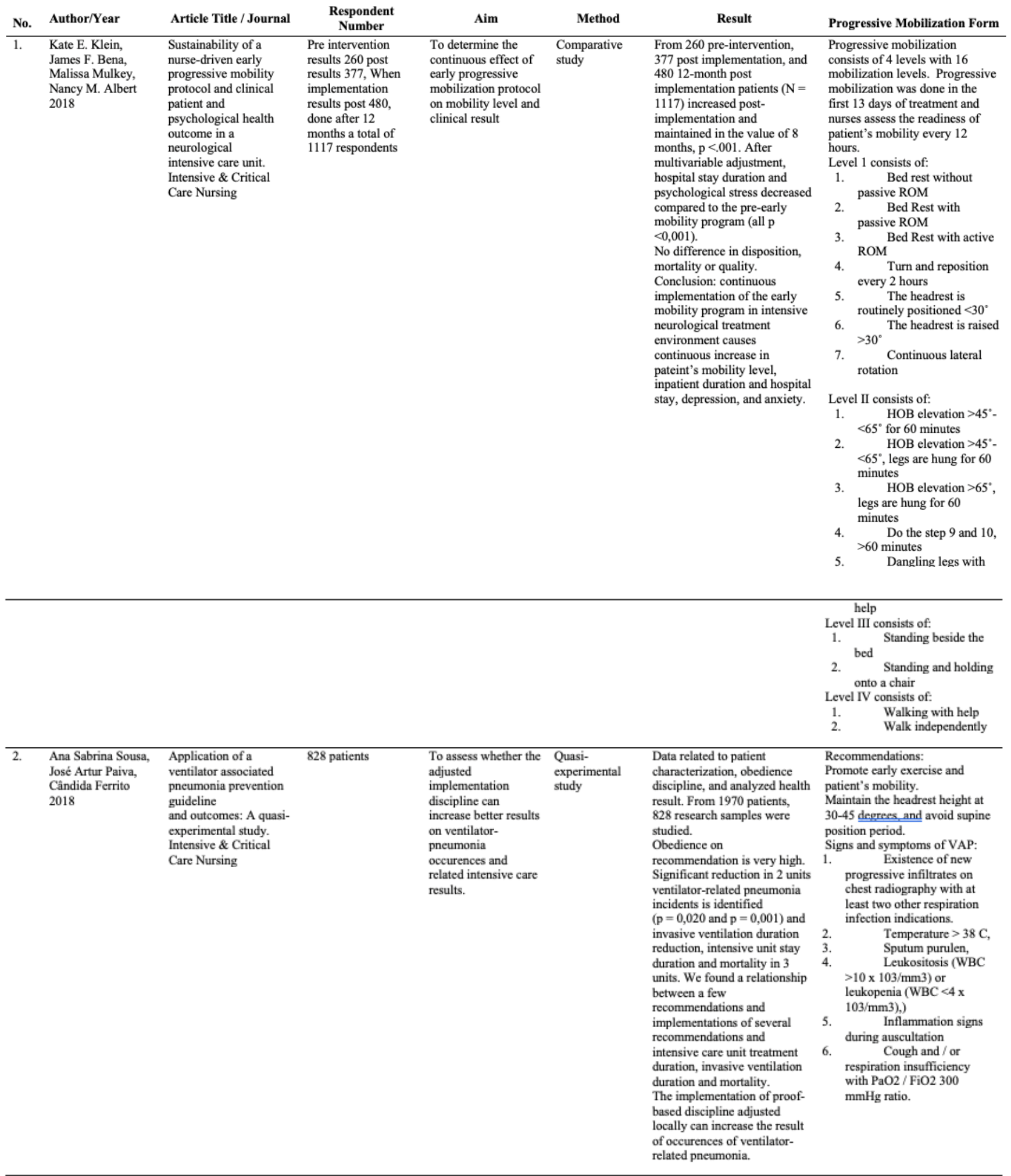




\begin{tabular}{|c|c|c|c|c|c|c|c|}
\hline 3. & $\begin{array}{l}\text { Alessandra Negro, } \\
\text { RN, Luca Cabrini, } \\
\text { MD, Rosalba } \\
\text { Lembo, MSc, } \\
\text { Giacomo Monti, } \\
\text { MD, Mauro Dossi, } \\
\text { RN, CNS, } \\
\text { Arianna Perduca, } \\
\text { RN, Sergio } \\
\text { Colombo, MD, } \\
\text { Monica Marazzi, } \\
\text { RN, HNIC, Giulia } \\
\text { Villa, MScN, RN, } \\
\text { Duilio Manara, } \\
\text { MScN, RN, } \\
\text { Giovanni Landoni, } \\
\text { MD, and Alberto } \\
\text { Zangrillo, MD } \\
\text { 2018 }\end{array}$ & $\begin{array}{l}\text { Early progressive } \\
\text { mobilization in the } \\
\text { intensive care unit } \\
\text { without dedicated } \\
\text { personnel. } \\
\text { Canadian Journal of } \\
\text { Critical Care Nursing }\end{array}$ & $94 \mathrm{ICU}$ patients & $\begin{array}{l}\text { To assess the } \\
\text { worthiness and safety } \\
\text { of early progressive } \\
\text { mobilization protocol } \\
\text { implemented with } \\
\text { personnel limitation } \\
\text { and as a part of } \\
\text { ABCDE governance. }\end{array}$ & $\begin{array}{l}\text { Quasi } \\
\text { experimental }\end{array}$ & $\begin{array}{l}\text { During the research, } 482 \\
\text { patients were treated in the } \\
\text { ICU and } 94(19,5 \%) \text { were } \\
\text { mobilized. Patients who were } \\
\text { not mobilized were usually } \\
\text { surgery patients. We } \\
\text { conducted } 356 \text { mobilization } \\
\text { sessions. We found significant } \\
\text { improvement by time when } \\
\text { patients were mobilized while } \\
\text { using ventilation mechanism. } \\
\text { Four minor side effects } \\
\text { occurred in the first } 3 \text { months } \\
\text { and did not happen afterwards. } \\
\text { All practices were completed } \\
\text { and upon finishing the } \\
\text { mobilization there were not } \\
\text { any consequences. The } \\
\text { implementation of early and } \\
\text { progressive mobilization } \\
\text { protocol is worthy and safe, } \\
\text { even without required } \\
\text { personnel, but the number of } \\
\text { patients that can be mobilized } \\
\text { is low. }\end{array}$ & $\begin{array}{l}\text { Progressive mobilization level } \\
\text { consists of } 6 \text { levels. } \\
\text { Level I; Head of Bed } \\
\text { (HOB) } 30^{\circ}-45^{\circ} \text { and } \\
\text { administering lateral } \\
\text { decubitus position at least } 1 \\
\text { shift. } \\
\text { Level II; HOB } 60^{\circ} \\
\text { for } 30 \text { minutes in } 1 \text { shift } \\
\text { Level III; HOB } 80^{\circ} \\
\text { for } 30 \text { minutes in } 1 \text { shift } \\
\text { Level IV; dangling } \\
\text { - } \quad \begin{array}{l}\text { feet twice a day } \\
\text { Level V; standing at }\end{array} \\
\text { the bed twice a day } \\
\text { Level VI; walking } \\
\text { Early mobilization was done for } \\
\text { the first time in the first } 48 \text { hours } \\
\text { after entering the room. } \\
\text { Security criteria are caution, } \\
\text { hemodynamic stability (no heart } \\
\text { ischemia, no vasopressor dosage } \\
\text { increase in the last } 2 \text { hours, no } \\
\text { arrhythmia in the last } 24 \text { hours) } \\
\text { and breath stability (FiO2 } \leq \\
0,65 \text {, PEEP < } 12 \text { cmH2O) }\end{array}$ \\
\hline 4. & $\begin{array}{l}\text { Karin Diserens, } \\
\text { Tiago Moreira, } \\
\text { Lorenz Hirt, } \\
\text { Mohamed Faouzi, } \\
\text { Jelena Grujic, Gilles } \\
\text { Bieler, Philippe } \\
\text { Vuadens and Patrik } \\
\text { Michel } \\
2011\end{array}$ & $\begin{array}{l}\text { Early mobilization out } \\
\text { of bed after } \\
\text { ischaemic stroke } \\
\text { reduces severe } \\
\text { complications but not } \\
\text { cerebral blood flow: a } \\
\text { randomized } \\
\text { controlled pilot trial. } \\
\text { Clinical Rehabilitation } \\
\text { Joumal }\end{array}$ & 50 patients & $\begin{array}{l}\text { To evaluate whether } \\
\text { early mobilization } \\
\text { after acute ischaemic } \\
\text { stroke proves better } \\
\text { than delayed } \\
\text { mobilization related } \\
\text { to medical } \\
\text { complication, and } \\
\text { whether it is secure } \\
\text { in relations with } \\
\text { neurological function } \\
\text { and brain blood flow. }\end{array}$ & $\begin{array}{l}\text { Quasi } \\
\text { experimental }\end{array}$ & $\begin{array}{l}\text { Eight out of } 50 \text { patients were } \\
\text { randomly excluded from the } \\
\text { pre-protocol analysis due to } \\
\text { early transfer to another } \\
\text { hospital. There were } 2 \text { ( } 8 \% \text { ) } \\
\text { severe complications in } 25 \\
\text { early mobilization patients and } \\
8(47 \%) \text { in } 17 \text { delayed } \\
\text { mobilization patients (P } \\
<0,006) \text {. There was no } \\
\text { difference in total } \\
\text { complication number or }\end{array}$ & $\begin{array}{l}\text { There are } 2 \text { kinds of progressive } \\
\text { mobilizations i.e. early } \\
\text { mobilization and delayed } \\
\text { mobilization. Early mobilization } \\
\text { starts from } 0^{\circ} \text { headrest position } \\
\text { for the first } 24 \text { then raised to } 45^{\circ} \\
\text { for } 24 \text { hours. Delayed } \\
\text { mobilization is when the } \\
\text { headrest position on the bed gets } \\
\text { higher for } \\
6 \text { days until standing beside the } \\
\text { bed. }\end{array}$ \\
\hline
\end{tabular}

\begin{tabular}{|c|c|c|c|c|c|c|c|}
\hline & & & & & & $\begin{array}{l}\text { clinical result. Of } 26 \text { patients } \\
\text { ( } 62 \% \text { ) who underwent the } \\
\text { serial transcranial Doppler } \\
\text { ultrasonography, no different } \\
\text { blood flow was found. The } \\
\text { research identified significant } \\
\text { reduction in severe } \\
\text { complication and no increase } \\
\text { in total complication with } \\
\text { early mobilization protocol } \\
\text { after the acute ischaemic } \\
\text { stroke. No effect on the 3- } \\
\text { month neurological result or } \\
\text { brain blood flow seen. } \\
\text { Mobilization for stroke } \\
\text { patients must begin on the first } \\
\text { day on the bed, followed with } \\
\text { quick mobilizations until } \\
\text { getting up from the bed. }\end{array}$ & $\begin{array}{l}\text { The highest level of progressive } \\
\text { mobilization activity reported } \\
\text { from the first level patients is the } \\
\text { limited standing activities beside } \\
\text { the bed and and in lateral } \\
\text { decubitus position. }\end{array}$ \\
\hline 5. & $\begin{array}{l}\text { Ni Wayan Rahayu } \\
\text { Ningtyas, RR Sri } \\
\text { Endang Pujiastuti, } \\
\text { Nina Indriyawati } \\
2017\end{array}$ & $\begin{array}{l}\text { Effectiveness of } \\
\text { Progressive } \\
\text { Mobilization Level I } \\
\text { and II on } \\
\text { Hemodynamic Status } \\
\text { and Decubitus Ulcer } \\
\text { Risk in Critically III } \\
\text { Patients. } \\
\text { Belitung Nursing } \\
\text { Journal }\end{array}$ & 40 respondents & $\begin{array}{l}\text { To assess the } \\
\text { effectiveness of } \\
\text { Level I and II } \\
\text { progressive } \\
\text { mobilization on } \\
\text { hemodynamic status } \\
\text { and decubitus risk in } \\
\text { critical patients. }\end{array}$ & $\begin{array}{l}\text { Quasy } \\
\text { experimental } \\
\text { study }\end{array}$ & $\begin{array}{l}\text { Paired t-test shows significant } \\
\text { differences between systolic } \\
\text { pressure, diastolic pressure, } \\
\text { MAP, heartbeats, and Braden } \\
\text { score after intervened with p- } \\
\text { value }<0,05 \text {. However, } \\
\text { repeated anova test indicates } \\
\text { that diastolic pressure values } \\
\text { in p }>0,05 \text {, thus it is not } \\
\text { possible to proceed to post- } \\
\text { hoc test. Level I and II } \\
\text { progressive mobilization to } \\
\text { critical patients can stabilize } \\
\text { systolic pressure }(52,46 \%) \text {, } \\
\text { stabilize PETA ( } 58,43 \%) \text {, } \\
\text { stabilize heartbeat }(68,99 \%) \text {, } \\
\text { and reduce decubitus risk } \\
\text { ( } 55,03 \%) \text { in the 7-day repeated } \\
\text { intervention. }\end{array}$ & $\begin{array}{l}\text { This research used Level I \& II } \\
\text { progressive mobilization. } \\
\text { The Level I consists of: } \\
\text { adjusting the Head of Bed } 30^{\circ} \\
\text { position, apply passive ROM } \\
\text { twice a day, run the Continuous } \\
\text { Lateraly Rotation Therapy } \\
\text { (CLRT) for } 2 \text { hours by tilting to } \\
\text { the right and left depending on } \\
\text { patient's ability. } \\
\text { In the Level II, patients were } \\
\text { given passive ROM } 3 \text { times a } \\
\text { day, adjust the Head of Bed } \\
\text { position to } 45^{\circ}-65^{\circ} \text { for } 15 \\
\text { minutes followed with training } \\
\text { the patient for } 20 \text { minutes. } \\
\text { This progressive mobilization } \\
\text { intervention is done in } 7 \text { days. }\end{array}$ \\
\hline
\end{tabular}




\begin{tabular}{|c|c|c|c|c|c|c|c|}
\hline & & & & & & $\begin{array}{l}\text { Level I and II progressive } \\
\text { mobilization can reduce } \\
\text { decubitus risk and stabilize } \\
\text { hemodynamic status in critical } \\
\text { patients. }\end{array}$ & \\
\hline 6. & $\begin{array}{l}\text { April Messer, RN, } \\
\text { MSN, CCRN } \\
\text { Linda Comer, RN, } \\
\text { PhD, CNE, LPC } \\
\text { Steve Forst, RN, } \\
\text { MSN, CNE } \\
2015\end{array}$ & $\begin{array}{l}\text { Implementation of a } \\
\text { Progressive } \\
\text { Mobilization } \\
\text { Program in a Medical- } \\
\text { Surgical Intensive Care } \\
\text { Unit. } \\
\text { Critical Care Nurse }\end{array}$ & 41 respondents & $\begin{array}{l}\text { To evaluate the effect } \\
\text { of education for the } \\
\text { practice and } \\
\text { knowledge of } \\
\text { progressive } \\
\text { mobilization program } \\
\text { in intensive care. }\end{array}$ & $\begin{array}{l}\text { Pre- } \\
\text { Experimental }\end{array}$ & $\begin{array}{l}\text { The score after education } \\
\text { intervention is significantly } \\
\text { higher than before the } \\
\text { intervention } \\
\text { ( } \mathrm{t}=2.02 ; \mathrm{P}<001) \text {. Overall } \\
\text { mobilization }(\mathrm{P}=0,04) \text { and } \\
\text { some }(\mathrm{P}=0,01) \text { increased } \\
\text { significantly after the } \\
\text { education. No significant } \\
\text { increase occurred in } \\
\text { ambulation process or when } \\
\text { making the paient stand. } \\
\text { Mobilization education is } \\
\text { effective and improve nurses' } \\
\text { knowledge of mobility use for } \\
\text { critical patients. } \\
\text { The education program also } \\
\text { influences how a nurse } \\
\text { implements mobility } \\
\text { intervention. Although } \\
\text { education administering } \\
\text { causes positive effects on } \\
\text { patients' mobility, leadership } \\
\text { and coaching are still the } \\
\text { essential components in } \\
\text { applying change. }\end{array}$ & $\begin{array}{l}\text { The progressive mobilization } \\
\text { activity done was the sitting } \\
\text { position on the bed, sitting on a } \\
\text { chair and ambulation. }\end{array}$ \\
\hline 7. & $\begin{array}{l}\text { Rene Merced } \\
\text { Rodriguez } \\
2017\end{array}$ & $\begin{array}{l}\text { Implementation of an } \\
\text { Early Progressive } \\
\text { Mobility Program in the } \\
\text { Intensive Care Units. } \\
\text { Health and Medical } \\
\text { Administration }\end{array}$ & $\begin{array}{l}20 \text { patients in the } \\
\text { ICU }\end{array}$ & $\begin{array}{l}\text { To evaluate EPM- } \\
\text { based programs in } \\
\text { improving } \\
\text { interdisciplinary } \\
\text { collaboration and } \\
\text { treatment }\end{array}$ & $\begin{array}{l}\text { Retrospective } \\
\text { study }\end{array}$ & $\begin{array}{l}\text { This research resulted } \\
\text { decrease in ventilator use } \\
\text { within } 1,2 \text { days in LOS ICU } \\
\text { and } 6,7 \% \text { reduction. The } \\
\text { average daily census dropped } \\
\text { from } 16,2 \text { in } 2015 \text { to } 14,7 \text { until }\end{array}$ & $\begin{array}{l}\text { The early progressive } \\
\text { mobilization program is proven } \\
\text { effective and done after entering } \\
\text { the ICU. The mobilization given } \\
\text { consists of repositions in bed for } \\
2 \text { hours and helping patient to }\end{array}$ \\
\hline
\end{tabular}

reduce complication,

ventilator days, $L O S$, and

overall cost for treatment. This

project showed standard

clinical practices based on
EBP guidelines and protocols

transferred into increased

teamwork, patient's result, and

hospital metric. 


\section{RESULT AND DISCUSSION}

Based on the article analysis, progressive mobilization proved that it positively affected pneumonia and decubitus in critical patients.

\subsection{The Effect of Progressive Mobilization on Pneumonia Occurrence}

Infection of lower respiration tubes is the leading cause of nosocomial infections in ICU treatments [6]. This condition can be distinguished by the existence of invasive ventilation mechanisms use when it occurs. Endotracheal intubation seems to trigger pneumonia ten times more likely [7]. Among pneumonia that occurs after the intubation, ventilator-associated pneumonia is defined as an infection after 48 hours of ventilation mechanism usage. Pneumonia occurrence indicates that microbiological confirmation as the infection cause of lung aggression [8]. During the invasive ventilation mechanism, patients' supine position causes liquid leakage from the supra glottal to the tracheobronchial chambers and the defense and invasion prevention systems from the lower air channels disturbed by trachea tubes and the positive ventilation pressure itself [9]. The use of tracheal intubation plays an essential role in inhalation as it blocks the natural protective mechanisms formed by airway obstruction, which in turn impairs mucociliary clearance, and ultimately distributes the flow of air secreted from the upper aerodynamic region to the subglottal space. This mechanism results in a secretion effect in the upper respiratory tract, gastrointestinal tract to endotracheal intubation device [9].

Pneumonia incidents in ICU care are called VentilatorAssociated Pneumonia (VAP). The use of invasive ventilation for a long time can increase the risk of developing VAP, and ICU LOS can lead to an increase [10]. The guidelines of VAP prevention recommendation are continuously developing as in the research done by Sousa et al. (2019) in Table 1, [11]. A significant reduction of invasive ventilation use duration was identified through these guidelines, along with the LOS ICU and morbidity rate during the intervention phase and VAP incidents decreased significantly.

\begin{tabular}{|c|l|}
\hline No. & \multicolumn{1}{|c|}{ Guideline recommendation } \\
\hline 1. & Avoid endotracheal ventilator if possible; \\
\hline 2. & $\begin{array}{l}\text { Assess and reduce daily sedation to the } \\
\text { minimum level }\end{array}$ \\
\hline 3. & $\begin{array}{l}\text { Replace ventilator circuits only when dirty or } \\
\text { broken }\end{array}$ \\
\hline 4. & $\begin{array}{l}\text { Raise headrest in the bed to } 30^{\circ}-45^{\circ} \text {, avoid the } \\
\text { supine position }\end{array}$ \\
\hline 5. & $\begin{array}{l}\text { Start with progressive exercise and movement } \\
\text { ETT is maintained at a pressure of } 20 \text { to } 30\end{array}$ \\
\hline 6. & $\begin{array}{l}\text { Apply mouth cleanliness with chlorhexidine } \\
0,12 \% \text { or } 0,2 \% \text { treatment according to these } \\
\text { steps: }\end{array}$ \\
\hline
\end{tabular}

\begin{tabular}{|l|l|}
\hline- & $\begin{array}{l}\text { Aspiration of secretions in the mouth } \\
\text { and nose above the pressure of ETT. }\end{array}$ \\
- & $\begin{array}{l}\text { Clean the teeth and gums using a } \\
\text { sponge and gauze. }\end{array}$ \\
- & $\begin{array}{l}\text { Irrigation of } 15 \mathrm{ml} \text { of } 0.12 \% \text { or } 0.2 \% \\
\text { chlorhexidine takes } 30 \text { seconds } 2-4 \\
\text { times a day, followed by aspiration. }\end{array}$ \\
\hline
\end{tabular}

Table 2. VAP Prevention Recommendation Guideline

Source: Sousa, A. S., Ferrito, C., \& Paiva, J. A. (2019). Application of a ventilator-associated pneumonia prevention guideline and outcomes: A quasi-experimental study. Intensive and Critical Care Nursing, 51, 50-56.

This guideline has supported the implementation of the patient's mobilization program. Mobilizing ICU patients earlier during recovery is safely recommended and worthy by maintaining the bed's head in $30^{\circ}-45^{\circ}$ and avoiding supine position [12]. As the research conducted by Klein et al. (2018) went by, the EPM (Early Progresif Mobilization) program consisted of 4 up to 6 levels of developed mobilization. Progressive mobilization was done in the first 13 days of treatment, and nurses assessed the patient's readiness in mobility every 12 hours, implemented in ICU neurological patients for more than 34 months and independently resulted in neurological ICU and hospital LOS decrease. EPM also reduced complications from the hospital, including delirium decrease and functional ability improvement, fewer days of ventilator usage and less VAP level, getting up earlier from the bed, a bigger chance of going back home and smaller treatment cost. The results obtained added to the practitioner's confidence level in initiating and maintaining progressive EPM in the neurological ICU area [13].

Alessandra Negro et al. (2018) stated that the initial and progressive program in the ICU consisting of 6 stages was proven to be feasible and safe, even more advanced, even though there were still fewer people in the implementation of the mobilization of the physical function rehabilitation program, after leaving the ICU it was proven ineffective for the initial active and passive mobilization. Initiated in the first 48 hours after ICU admission was the most effective strategy [15]. Research by Alessandra Negro et al. (2018), mobilization for critical patients by using a ventilator-that a nurse used required the support of a physiotherapist due to his help of achieving better, more extended, and personal mobilization, and also he could act as an educator for all ICU staff and functions as a mobilization team applying the mobilization protocol led by the nurses. Research conducted by Soussan et al. (2019) added the previous research where critical patients' mobilization during the hospital transfer process could cause aspiration by increasing tracheal tube movement risks. The liquid flow was stuck through the lower airway channel. Therefore, the mobilization can be conducted in stages after being in an ICU treatment room [14] 
In developing progressive mobilization practices on critical pneumonia patients in Indonesia, many nurses or patients are not encouraged to implement mobilization progressively due to the concerns of the effects on patients' condition, and some hospital institutions have not possessed standard operational procedure for this concept [11]. A similar study discussed the occurrence of ventilator-related pneumonia (VAP) in the intensive care unit as well as the impact of chest mobilization and physical therapy by Hendra \& Huraini (2011), with a quasi-experiment comparison design of static group (post-test only control group design), in line with several studies of this review

Table 3. Mobility Levels of the Early Mobilization Protocol

\begin{tabular}{|c|c|c|c|c|c|}
\hline \multicolumn{6}{|c|}{$\begin{array}{l}\text { Mobilization Levels of The Early } \\
\text { Mobilization Protocol }\end{array}$} \\
\hline $\begin{array}{c}\text { Level } \\
\text { I }\end{array}$ & $\begin{array}{c}\text { Level } \\
\text { II }\end{array}$ & $\begin{array}{c}\text { Level } \\
\text { III }\end{array}$ & $\begin{array}{c}\text { Level } \\
\text { IV }\end{array}$ & $\begin{array}{c}\text { Level } \\
\mathrm{V}\end{array}$ & $\begin{array}{c}\text { Level } \\
\text { VI }\end{array}$ \\
\hline $\begin{array}{l}\text { Head of } \\
\text { Bed } \\
\text { (HOB) } \\
30^{\circ}-45^{\circ} \\
\text { and } \\
\text { lateral } \\
\text { decubitus } \\
\text { position } \\
\text { at least } 1 \\
\text { shifting }\end{array}$ & $\begin{array}{l}\mathrm{HOB} \\
60^{\circ} \\
\text { for } 30 \\
\text { minut } \\
\text { es in } 1 \\
\text { shift }\end{array}$ & $\begin{array}{l}\mathrm{HOB} \\
80^{\circ} \\
\text { for } 30 \\
\text { minut } \\
\text { es in } \\
1 \\
\text { shift }\end{array}$ & $\begin{array}{l}\text { Dang } \\
\text { ling } \\
\text { feet } \\
\text { positi } \\
\text { on } \\
\text { twice } \\
\text { a day }\end{array}$ & $\begin{array}{l}\text { Standi } \\
\text { ng } \\
\text { from } \\
\text { the } \\
\text { bed } \\
\text { twice } \\
\text { a day }\end{array}$ & $\begin{array}{l}\text { Walkin } \\
\mathrm{g}\end{array}$ \\
\hline
\end{tabular}

result which used experimental and comparing groups, time and samples taken are different because the research was quickly conducted, only in around one month and the samples were taken was slightly compared to this review research within 6 months - 1 year and used vast samples. After two days in the ICU, mobilization was done following. The research conducted by Alessandra Negro et al. (2018) started the progressive mobilization in the first 48 hours [16]. The exercise given was patients' changing position every 2 hours, i.e., tilt to the left, supine and tilt to the right, different from Sousa et al.'s (2019) research, which avoided supine position instead of implementing HOB position $30^{\circ}-45^{\circ}$. Thus, the result differed were no significant distinction occurring between mobilization (ambulation) and chest physiotherapy, which was conducted according to the room's routine, with the mobilization and chest physiotherapy followed the SOP ( $p$ $>0,05),[11]$. This result indicates that it requires improvement of mobilization implementation under appropriate SOP with 6 progressive mobilization levels and further research with more significant samples and longer duration.

\subsection{The Effect of Progressive Mobilization on Decubitus Occurrence}

A progressive mobilization program is the mobilization of ventilated adult patients in the ICU and is something different in practice that can reduce physical and mental disabilities after the patient is discharged from the hospital [17]. Rahayu et al. (2017) proved that decubitus was based on the patient's dependent level. Patients with minimum treatment did not risk suffering decubitus, unlike those who required partial or total treatment. Rahayu et al. (2017) used level I and II progressive mobilizations and did not encounter any worse complications when done with careful protocol by controlling the head position in the bed after 52 hours post-stroke [1]. Progressive mobilization had a good effect with a time of 18 hours per day for 2 hours. Diserens et al. (2012) showed the mobilization implementation of stroke patients [18]. The movement of stroke patients should be trained when they first entered the hospital. The time was 52 hours without waiting for 6-7 days of rest. The highest level of progressive mobilization activity achieved by the patient was the limited activity beside the bed in standing, and lateral decubitus positions with early mobilization started from $0^{\circ}$ position for the first 24 hours then the headrest was raised to $45^{\circ}$ for the next 24 hours, so it all began in the first 48 hours after admitted in the ICU [18].

In Alessandra Negro et al. (2018) research, the progressive mobilization position was developed to prevent decubitus [15]. These phases were dangling (e.g., sit on the edge of the patient's bed), getting up from the bed (for example, the patient sits by the bed), awakens from the bed (for example, being able to stand beside the patient's bed and sit on a chair), also walking short distances with the assistance of staff (Table 2)

Source: Alessandra Negro, R., Luca Cabrini, M., Rosalba Lembo, Ms., Giacomo Monti, M., Mauro Dossi, RN, C., Arianna Perduca, RN, Sergio Colombo, M., Monica Marazzi, RN, HNIC, Giulia Villa, MScN, R., Duilio Manara MScN, RN, Giovanni Landoni, M., \& Alberto Zangrillo, M. (2018). Early progressive mobilization in the intensive care unit without dedicated personnel. The Canadian Journal of Critical Care Nursing, 29(3), 26.

The nurses conducted the procedure with the outcome criteria of patients who had successfully assessed the ABCDE Protocols (the only exception was patients dying and discharged in the next few hours) [15]. Patients who were successful when the checklist was performed did not receive immobilization measures taking into account the criteria, comfort in stabilizing hemodynamics (no ischemia, no increase in vasopressor dose during the last 2 hours, no heart attack, arrhythmia last 24 hours, and respiratory stability ( $\mathrm{FiO} 2 \leq 0)$. , 65, PEEP $<12 \mathrm{cmH} 2 \mathrm{O})$. Then, these conditions must be avoided, i.e., channel, tube or any equipment release, arteries pressure averages $<55 \mathrm{mmHg}$ or $>140 \mathrm{mmHg}$, the presence of new arrhythmias, cardiac arrest and saturation oxygen $<85 \%$, [15].

In the research of Messer (2015), effective education intervention improved nurses' knowledge of immobility risks and the importance of mobilization on ICU patients. With the mobilization aim and protocol, all patients who fulfilled the inclusion criteria received several mobility intervention levels [2]. In the implementation, nurses in critical treatment seldom run the progressive mobilization 
program due to their worries to involve patients in more activities and lack experience in mobilizing critical patients [19]. Designing education in the form of mobility training is required to facilitate nurses' understanding of both beneficial and side effects of mobilization progressively, to help nurses overcome the obstacles in applying the mobilization, to boost understanding of the importance of mobility, and to motivate changes during the mobilization [5].

Related research for the effect of progressive mobilization on decubitus in Indonesia is way more than pneumonia. However, it had obstacles in the implementation because progressive mobilization was harder to do in practice due to the lack of resources, nurses' knowledge of patients' condition was limited, and the application was not according to the procedures [1]. Studies similar to the effect of progressive level I mobilization in decubitus patients and changes in oxygen saturation yields for critically ill patients on a ventilator in Dr. ICU. Moewardi Surakarta by Zakiyyah (2014), using Quasy Experimental and pre and post-test. It used level I progressive mobilization in administering head of bed position to $30^{\circ}$ with supine position, then tilting the sleeping position to the left and right for 2 hours. Pauses between each act were around 5-10 minutes. Every day, this was done every 2 hours, and researchers did decubitus scoring observation on the last intubation day. This research followed the one conducted by Rahayu et al. (2017) in Indonesia, which also used level I and II progressive mobilizations for using 18 hours per day for 2 hours and research from Alessandra Negro et al. and also the research was done by Alessandra Negro et al. (2018) with I - VI progressive mobilization levels practiced every day by each patient.

A bit different from Diserens et al. (2012) by recommending limited near-bed activities of standing and lateral decubitus positions, but with the headrest raised to $45^{\circ}$ for 1 hour and began in the first 48 hours after entering the ICU [20]. The result found by Zakiyyah (2014) displayed that the intervention group scored the Braden scale 14.53 from previously 13.53 , and in the control group, the score decreased from 12.60 Braden scale to 11.00. The intervention group did not result in any decubitus, while the control group resulted in 4 patients suffering decubitus on the third day. Level I progressive mobilization significantly proved in preventing decubitus $(\mathrm{U}=21 ; \mathrm{p}=0,00)$ and increase oxygen saturation significantly $(U=28 ; p=0,000)$; therefore, the level I progressive mobilization could prevent decubitus and maintain values on the oxygen saturation of critical patients using a ventilator. This review result kept referring to the patients' safety criteria and designed an education in mobility training to facilitate nurses' understanding of beneficial and side effects of progressive mobilization [21].

\section{CONCLUSION AND SUGGESTION}

Progressive mobilization prevents pneumonia occurrences in ICU treatment known as Ventilator-
Associated Pneumonia (VAP). Progressive mobilization also resists the occurrence of decubitus, which bases upon patients' dependent level. The mobilization exercise was conducted progressively from Level 1 - Level VI with HOB activity to $30^{\circ}-45^{\circ}$ until the patient could walk with 2 -hour duration, starting from the first 48 hours after being admitted in the critical treatment was conducted every day for 7-13 treatment days. Hence, it needs training implementation for nurses who work in critical services for more knowledge and civilizing clinical practices related to progressive mobilization.

\section{AUTHORS' CONTRIBUTIONS}

AUTHOR CONTRIBUTIONS HRM, NC: Created significant contributions to conception and design, or acquisition of data, or analysis and interpretation of data. HRM, NC: Engaged in drafting the manuscript or revising it critically for important intellectual content. HRM, NC: Provided final approval of the version to be published. HRM, NC: Approved to be responsible for all aspects of the work in ensuring that questions related to the accuracy or integrity of any part of the work are appropriately investigated and resolved.

\section{ACKNOWLEDGMENTS}

This paper is part of a study supported by the Institute of Research and Community Development (LP3M), Universitas Muhammadiyah Yogyakarta. The authors thank the LP3M UMY.

\section{REFERENCES}

[1] Rahayu, N. W. N, Pujiastuti, R. S. E., \& Indriyawati, N, Effectiveness of Progressive Mobilization Level I and II on Hemodynamic Status and Decubitus Ulcer Risk in Critically Ill, 2017, Patients Belitung Nursing Journal, 3(6), 662-669. https://doi.org/10.33546/bnj.289

[2] Messer, A, Progressive Mobilization Program in a Medical-. 35(5), 28-43, 2015

[3] Ecklund, M. M., \& Bloss, J. W, Progressive mobility as a team effort in transitional care 2015, Critical Care Nurse, 35(3), 62-68. https://doi.org/10.4037/ccn2015622

[4] Schweickert, W. D., \& Kress, J. P, Implementing early mobilization interventions in mechanically ventilated patients in the ICU 2011. Chest, 140(6), 1612-1617. https://doi.org/10.1378/chest.10-2829

[5] Vollman, B. K. M., \& Bassett, R, Transforming the culture 2014: The key to hardwiring early. September 7-11.

[6] Bouadma, L., Sonneville, R., Garrouste-Orgeas, M., Darmon, M., Souweine, B., Voiriot, G., Kallel, H., Schwebel, C., Goldgran-Toledano, D., Dumenil, A. S., Argaud, L., Ruckly, S., Jamali, S., Planquette, B., Adrie, C., Lucet, J. C., Azoulay, E., \& Timsit, J. F, Ventilator-Associated Events: Prevalence, Outcome, 
and Relationship with Ventilator-Associated Pneumonia. Critical Care Medicine 2015,43(9),17981806.

https://doi.org/10.1097/CCM.0000000000001091

[7] Wang, Y., Eldridge, N., Metersky, M. L., Verzier, N. R., Meehan, T. P., Pandolfi, M. M., Foody, J. A. M., Ho, S. Y., Galusha, D., Kliman, R. E., Sonnenfeld, N., Krumholz, H. M., \& Battles, J, National trends in patient safety for four common conditions, 2005-2011. New England Journal of Medicine 2014, 370(4),341351. https://doi.org/10.1056/NEJMsa1300991

[8] Leone, M., Bouadma, L., Bouhemad, B., Brissaud, O., Dauger, S., Gibot, S., Hraiech, S., Jung, B., Kipnis, E., Launey, Y., Luyt, C. E., Margetis, D., Michel, F., Mokart, D., Montravers, P., Monsel, A., Nseir, S., Pugin, J., Roquilly, A.Chanques, G, Hospital-acquired pneumonia in ICU. Anaesthesia Critical Care and Pain Medicine 2018, 37(1), 83-98. https://doi.org/10.1016/j.accpm.2017.11.006

[9] Blot, S. I., Poelaert, J., \& Kollef, M. How to avoid microaspiration? A key element for the prevention of ventilator-associated pneumonia in intubated ICU patients 2014. BMC Infectious Diseases, 14(1), 2-7. https://doi.org/10.1186/1471-2334-14-119

[10] De Miguel-Díez, J., López-De-Andrés, A., Hernández-Barrera, V., Jiménez-Trujillo, I., MéndezBailón, M., De Miguel-Yanes, J. M., Del Rio-Lopez, B., \& Jiménez-García, R, Decreasing incidence and mortality among hospitalized patients suffering a ventilator-associated pneumonia: Analysis of the Spanish national hospital discharge database from 2010 to 2014, Medicine (the United States 2017), 96(30) https://doi.org/10.1097/MD.0000000000007625

[11] Sousa, A. S., Ferrito, C., \& Paiva, J. A. Application of a ventilator-associated pneumonia prevention guideline and outcomes: A quasi-experimental study. Intensive and Critical Care Nursing, 2019, 51, 50-56. https://doi.org/10.1016/j.iccn.2018.10.001

[12] Castro-Avila, A. C., Serón, P., Fan, E., Gaete, M., \& Mickan, S. Effect of early rehabilitation during intensive care unit stay functional status: Systematic review and meta-analysis 2015. PL ONE, 10 (7), 121. https://doi.org/10.1371/journal.pone.0130722

[13] Klein, K. E., Bena, J. F., Mulkey, M., \& Albert, N. M, Sustainability of a nurse-driven early progressive mobility protocol and patient clinical and psychological health outcomes in a neurological intensive care unit. Intensive and Critical Care Nursing, 2018, 45, 11-17. https://doi.org/10.1016/j.iccn.2018.01.005

[14] Soussan, R., Schimpf, C., Pilmis, B., Degroote, T., Tran, M., Bruel, C., \& Philippart, F, Ventilatorassociated pneumonia: The central role of transcolonization. Journal of Critical Care, 2019, 50, 155-161. https://doi.org/10.1016/j.jcrc.2018.12.005

[15] Alessandra Negro, R., Luca Cabrini, M., Rosalba Lembo, Ms., Giacomo Monti, M., Mauro Dossi, RN, C., Arianna Perduca, RN, Sergio Colombo, M., Monica Marazzi, RN, HNIC, Giulia Villa, MScN, R.,
Duilio Manara MScN, RN, Giovanni Landoni, M., \& Alberto Zangrillo, M, Early progressive mobilization in the intensive care unit without dedicated personnel. The Canadian Journal of Critical Care Nursing, 2018, 29(3), 26.

[16] Hendra, \& Huraini, E, Pengaruh Mobilisasi Dan Fisioterapi Dada Terhadap Kejadian VentilatorAssociated Pneumonia Di Unit Perawatan Intensif. NERS Jurnal Keperawatan 2011, 7(2), 121. https://doi.org/10.25077/njk.7.2.121-129.2011

[17] Reames, C. D., Price, D. M., King, E. A., \& Dickinson, S, Mobilizing Patients Along the Continuum of Critical Care. Dimensions of Critical Care Nursing 2016, 35(1), 10-15. https://doi.org/10.1097/DCC.0000000000000151

[18] Diserens, K., Moreira, T., Hirt, L., Faouzi, M., Grujic, J., Bieler, G., Vuadens, P., \& Michel, P, Early mobilization out of bed after ischaemic stroke reduces severe complications but not cerebral blood flow: A randomized controlled pilot trial. Clinical Rehabilitation, 2012, 26(5), 451-459. https://doi.org/10.1177/0269215511425541

[19] Jackson, J. C., Santoro, M. J., Ely, T. M., Boehm, L., Kiehl, A. L., Anderson, L. S., \& Ely, E. W, Improving patient care through the prism of psychology: Application of Maslow's hierarchy to sedation, delirium, and early mobility in the intensive care unit. Journal of Critical Care, 2014, 29(3), 438-444. https://doi.org/10.1016/j.jcrc.2014.01.009

[20] Diserens, K., Moreira, T., Hirt, L., Faouzi, M., Grujic, J., Bieler, G., Vuadens, P., \& Michel, P, Early mobilization out of bed after ischaemic stroke reduces severe complications but not cerebral blood flow: A randomized controlled pilot trial. Clinical Rehabilitation, 2012, 26(5), 451-459. https://doi.org/10.1177/0269215511425541

[21] Roberts, M., Johnson, L. A., \& Lalonde, T. L, Early mobility in the intensive care unit: Standard equipment vs. a mobility platform. American Journal of Critical Care, 2014, 23(6), 451-457. https://doi.org/10.4037/ajcc2014878

[22] Zakiyyah, Syifa, Pengaruh Mobilisasi Progresif Level I: Terhadap Ventilator Di Ruang Icu Rsud Dr. Moewardi Surakarta, 2014 